\title{
ELEMEN PEMBENTUK PERMUKIMAN TRADISIONAL KAMPUNG NAGA
}

\author{
Syavana Fairuzahira, Wara Indira Rukmi, Kartika Eka Sari \\ Jurusan Perencanaan Wilayah dan Kota Fakultas Teknik Universitas Brawijaya \\ Jalan Mayjen Haryono 167 Malang 65145 -Telp (0341)567886 \\ e-mail: syavanafz@gmail.com
}

\begin{abstract}
ABSTRAK
Permukiman tradisional merupakan permukiman yang masih menjaga tradisi, budaya, adat-istiadatnya. Elemenelemen ekistik adalah elemen yang membentuk suatu permukiman, yang merupakan hasil interaksi antara manusia dengan lingkungannya. Kampung Naga yang merupakan salah satu permukiman tradisional di Jawa Barat yang masih bertahan hingga kini, terbentuk dari elemen ekistik. Tujuan pada penelitian ini, adalah mengidentifikasi elemen pembentuk permukiman dari Doxiadis (1968) yang terdapat di permukiman tradisional Kampung Naga. Metode penelitian adalah deskriptif-eksplanatif dengan metode analisis yang digunakan adalah analisis deskriptif dan analisis behaviour mapping. Variabel penelitian ini adalah elemen ekistik yang terdiri dari fisik alam, manusia dan masyarakat, bangunan, dan jaringan. Hasil penelitian ini diketahui bahwa di dalam permukiman tradisional Kampung Naga, seluruh elemen pembentuk permukiman, content dan container, memiliki sifat timbal balik, dengan elemen manusia dan masyarakat yang paling berkontribusi dalam membentuk permukiman tradisional.
\end{abstract}

Kata Kunci : elemen ekistik, permukiman tradisional, Kampung Naga

\begin{abstract}
Traditional settlements are settlements that still maintain their traditions, culture and customs. Ecistics elements are elements that form a settlement, which is the result of interaction between humans and their environment. Kampung Naga, which is one of the traditional settlements in West Java that still survive today, is formed from ecistic elements. In this study, researchers wanted to identify settlement-forming elements from Doxiadis (1968) found in Kampung Naga. The research method is descriptive-explanatory with the analytical method used is descriptive analysis and behavior mapping analysis. This research variable is an ecistic element consisting of physical nature, humans and society, buildings, and networks. The results of this study note that in Kampung Naga settlements, is that all the elements forming settlement, the content and container, have a reciprocal nature, with man and society as the elements that contributes mostly into forming traditional settlements.
\end{abstract}

Keywords: ecistics element, traditional settlement, Kampung Naga

\section{PENDAHULUAN}

Permukiman merupakan bentuk tatanan kehidupan yang di dalamnya mengandung unsur fisik dalam arti permukiman merupakan wadah aktifitas tempat bertemunya komunitas untuk berinteraksi sosial dengan masyarakat (Niracanti, 2001). Doxiadis (1968) memberikan pengertian yang sedikit berbeda, dimana permukiman merupakan hasil dari adanya interaksi antara manusia dengan lingkungannya yang bersifat dinamis, selalu berkembang. permukiman terdiri atas content atau isi, yaitu manusia dan container atau tempat fisik dimana manusia tinggal (Jencks \& Kropf, 1981). Elemen-elemen pembentuk permukiman meliputi nature, man, society, shells, dan network, dimana content dari permukiman adalah man dan society, sedangkan containernya adalah nature, shells, dan network (Doxiadis, 1968).

Nature merupakan lingkung an alamiah yang menjadi wadah untuk manusia (man) beraktivitas. Manusia sebagai makhluk sosial pada akhirnya akan membentuk kelompok-kelompok sosial dalam rangka bertahan hidup dan memenuhi kebutuhannya. Kelompok-kelompok ini kemudian mengembangkan norma dan relasi internal dan dikenali sebagai masyarakat (society) tertentu. Dari perkembangan fisik lingkungan, lingkungan alamiah tidaklah cukup untuk menyediakan perlindungan terhadap aktivitas manusia. Masyarakat kemudian mengubah sebagian lingkungan alamiah untuk menjadi hunian (shell). Perkembangan shell yang semakin kompleks kemudian harus dilengkapi dengan elemen penunjang aktivitas yang menghubungkan hunian-hunian dalam satu sistem lingkungan. Jaringan penghubung antar shell ini kemudian dikenal dengan network.

Permukiman tradisional sering direpresentasikan sebagai tempat yang masih memegang nilai-nilai adat dan budaya yang berhubungan dengan nilai kepercayaan atau agama yang bersifat khusus atau unik pada suatu masyarakat tertentu yang berakar dari tempat tertentu pula di luar determinasi sejarah (Sasongko 
2005). Permukiman tradisional merupakan permukiman yang masih memegang kepercayaan terhadap leluhur dan tersusun atas elemen-elemen seperti nilai kepercayaan, adat-istiadat, dan budaya, dimana budaya merupakan faktor penentu yang dominan (Ayunurafidha, 2015). Permukiman tradisional sering digambarkan sebagai tempat yang memegang teguh nilai adat dan kebudayaan dari leluhur, yang seringkali dihubungkan dengan kepercayaan yang bersifat unik pada suatu masyarakat (Chrysler, 2000 dalam Sasongko, 2005).

Penelitian terdahulu di Kampung Adat Lewohala, menyatakan bahwa seluruh elemen permukiman disana menciptakan dinamika kehidupan yang saling berhubungan satu dengan yang lain. Seluruh fungsi elemen berbentuk sederhana, namun dapat mewakili fungsi penting dalam keberlangsungan kehidupan disana, hingga, dapat bertahan dalam ratusan tahun (Payong, 2016).

Menurut Dariwu (2016), keberlanjutan masyarakat nelayan di Pesisir Pantai Sindulang Satu dilihat dari kondisi permukiman dari prinsip teori ekistik. Kesimpulan yang diambil dari penelitian ini adalah bahwa elemen yang memberi kontribusi paling besar adalah elemen masyarakat/society karena kuatnya hubungan kelompok nelayan disana. Namun, ketidakseimbangan pada satu elemen akan mempengaruhi elemen-elemen lainnya dan sistem hubungan yang terjadi diantara elemen-elemen tersebut, maka untuk keberlanjutan suatu permukiman, kelima elemen tersebut harus mencapai titik keseimbangan (Doxiadis, 1968 dalam Dariwu et al., 2016).

Kampung Naga yang juga merupakan suatu permukiman, terdiri dari elemen-elemen yang disebutkan oleh Doxiadis (1968). Jenis permukiman Kampung Naga adalah kampung tradisional yang mana masih mempertahankan nilai dan adat istiadatnya, sehingga dapat dilihat bahwa content permukimannya lebih menunjukan identitas kampung. Penelitian ini bertujuan untuk mengidentifikasi elemen-elemen yang berperan dalam membentuk permukiman tradisional Kampung Naga, hingga diketahui elemen mana yang paling berpengaruh dalam permukiman tradisional.

\section{METODE PENELITIAN}

Metode penelitian yang digunakan adalah metode deskriptif-eksplanatif. Metode deskriptif adalah prosedur pemecahan masalah dengan cara menggambarkan atau melukiskan keadaan objek penelitian berdasarkan fakta yang tampak di lapangan (Nawawi \& Martini, 1996). Penelitian eksplanatif dilakukan untuk menemukan penjelasan tentang mengapa suatu kejadian atau gejala terjadi dengan tujuan menghubungkan pola-pola yang berbeda namun memiliki keterkaitan. Jadi metode deskriptif-eksplanatif adalah penelitian dengan pemecahan masalah yang digali untuk menemukan penjelasan tentang mengapa suatu kejadian terjadi berdasarkan faktafakta yang terjadi di lapangan.

\section{Lokasi Penelitian}

Penelitian ini dilakukan di Kampung Naga, Desa Neglsari, Kecamatan Salawu, Kabupaten Tasikmalaya. Kampung Naga berada di Dusun Naga memiliki luas wilayah 10 hektar yang terdiri dari lahan permukiman, kebun, sawah, hutan kramat, dan hutan lindung. Namun, yang termasuk tanah adat hanya seluas 1,5 hektar dan dibatasi oleh kandang jaga disekeliling tanah adat Kampung Naga. Kampung Naga bagian barat dan utara memiliki batasan berupa sungai, dan areal persawahan warga, serta terdapat hutan leluhur dan hutan larangan disebelah barat dan timur.

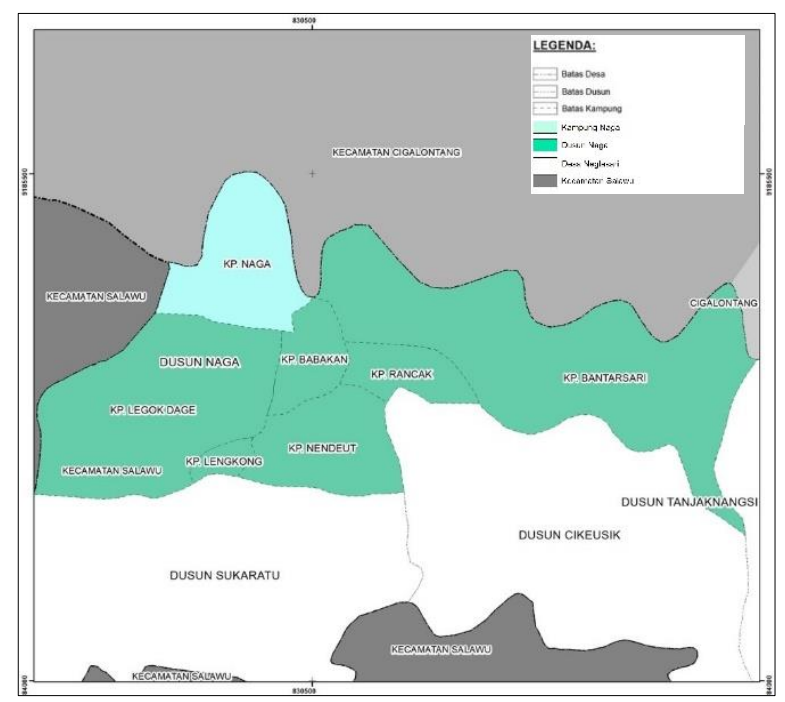

Gambar 1. Lokasi Penelitian

\section{Variabel Penelitian}

Berangkat dari rumusan masalah dalam penelitian ini, dibutuhkan variabel dalam membantu peneliti untuk menjawab rumusan masalah yang ada. Variabel yang digunakan terdiri dari elemen ekistik (Doxiadis, 1968; Rakhmawati, et al, 2009).

\section{Tabel 1. Variabel Penelitian}

\begin{tabular}{lll}
\hline Variabel & Sub-Variabel & Sumber \\
\hline Nature & Topografi & \\
/Fisik Alam & Kelerengan & \\
\hline
\end{tabular}




\begin{tabular}{|c|c|c|}
\hline Variabel & Sub-Variabel & Sumber \\
\hline & $\begin{array}{l}\text { Vegetasi/tanaman } \\
\text { Hidrologi }\end{array}$ & \multirow{9}{*}{$\begin{array}{l}\text { Doxiadis, 1968; } \\
\text { Rakhmawati, et al, } \\
2009\end{array}$} \\
\hline Man & Kegiatan religi & \\
\hline /Manusia & Bentuk-bentuk & \\
\hline Society / & kebudayaan & \\
\hline Masyarakat & Nilai-nilai moral & \\
\hline $\begin{array}{l}\text { Shell } \\
\text { /Bangunan }\end{array}$ & $\begin{array}{l}\text { Jenis dan fungsi } \\
\text { bangunan }\end{array}$ & \\
\hline & $\begin{array}{l}\text { Organisasi dan pola } \\
\text { bangunan }\end{array}$ & \\
\hline & $\begin{array}{l}\text { Peletakan dan arah } \\
\text { hadap }\end{array}$ & \\
\hline $\begin{array}{l}\text { Network } \\
\text { /Jaringan }\end{array}$ & $\begin{array}{ll}\text { Jalan } & \text { dan } \\
\text { aksesibilitas } & \end{array}$ & \\
\hline
\end{tabular}

\section{Metode Pengumpulan Data}

Metode pengumpulan data berupa survei primer yang dilakukan dengan cara observasi dan wawancara, serta studi literatur. Observasi ini dilakukan terhadap objek penelitian yaitu permukiman adat Kampung Naga. Wawancara dilakukan kepada informan yang dipilih menggunakan teknik purposive sampling. Penggunaan purposive sampling pada penelitian ini guna mendapat jawaban yang tepat sasaran. Informan tersebut adalah pemangku adat, sesepuh adat, dan pemandu wisata.

\section{Metode Analisis}

\section{Analisis Deskriptif}

Metode analisis deskriptif ditujukan untuk menggambarkan fenomena-fenomena yang ada, yang berlangsung pada saat ini atau saat yang lampau, yang dikumpulkan dari berbagai data yang dikumpulkan baik hasil wawancara atau pengamatan mengenai masalah yang diteliti (Saifullah, 2014; Winartha, 2006).

Menganalisis secara deskriptif yang memuat mengenai pembahasan fisik alam, kegiatan religi dan kegiatan kebudayaan, jenis dan fungsi bangunan, peran dan sifat ruang, serta jaringan jalan dan aksesibilitas. Aspek pembahasannya adalah sebagai berikut.

\section{Tabel 2. Analisis Deskriptif}

\begin{tabular}{|c|c|}
\hline Analisis Dekriptif & Pembahasan \\
\hline Nature/Fisik Alam & $\begin{array}{l}\text { Melihat bagaimana fisik alam } \\
\text { (topografi, kelerengan, dan } \\
\text { hidrologi) dalam membentuk } \\
\text { tata spasial Kampung naga }\end{array}$ \\
\hline Shell/Bangunan & $\begin{array}{l}\text { Melihat bagaimana jenis dan } \\
\text { fungsi bangunan, organisasi dan } \\
\text { pola bangunan, serta peletakan } \\
\text { dan arah hadap dalam } \\
\text { membentuk tata } \\
\text { Kampung naga }\end{array}$ \\
\hline
\end{tabular}

\begin{tabular}{ll}
\hline Analisis Dekriptif & Pembahasan \\
\hline Network/Jaringan & $\begin{array}{l}\text { Melihat bagaimana jalan dan } \\
\text { aksesibilitas dalam membentuk } \\
\text { tata spasial Kampung Naga }\end{array}$ \\
\hline
\end{tabular}

\section{Analisis Behaviour Mapping}

Behavior Mapping (Sommer, 1980 dalam Haryadi \& Setiawan, 1995) digambarkan dalam bentuk sketsa atau diagram mengenai suatu area dimana manusia melakukan berbagai kegiatannya. Behaviour mapping yang dilakukan dengan cara place centered mapping digunakan untuk melihat tradisi masyarakat Kampung Naga dan personcentered mapping menekankan pada pergerakan manusia pada periode waktu tertentu, dimana teknik ini berkaitan dengan tidak hanya satu tempat atau lokasi akan tetapi beberapa tempat/lokasi. Tahapan yang dilakukan adalah mengidentifikasi ruang-ruang yang digunakan oleh kelompok masyarakat dalam sketsa seting ruang. Tahap kedua adalah melakukan pengamatan dan pencatatan terhadap aktivitas kelompok masyarakat dalam tradisi yang dilakukan di Kampung Naga dan memberi tanda pada sketsa.

\section{HASIL DAN PEMBAHASAN}

\section{Fisik}

Kampung Naga berada di RT 01/RW 01 Desa Neglasari, Kecamatan Salawu, Kabupaten Tasikmalaya, Provinsi Jawa Barat. Desa Neglasari terletak di jalur jalan provinsi yang menghubungkan antara Kabupaten Garut dengan Kabupaten Tasikmalaya dan merupakan salah satu desa yang termasuk di Kecamatan Salawu. Kampung Naga berada di Dusun Naga memiliki luas wilayah 10 hektar yang terdiri dari lahan permukiman, kebun, sawah, hutan kramat, dan hutan lindung. Namun, yang termasuk tanah adat hanya seluas 1,5 hektar dan dibatasi oleh kandang jaga disekeliling tanah adat Kampung Naga. Jarak Kampung Naga ke Desa Neglasari \pm 800 m, jarak ke Kecamatan Salawu \pm 5 km, dan jarak ke ibu kota kabupaten $\pm 16 \mathrm{~km}$. Batas pemerintahan Kampung Naga di bagian barat adalah Bukit Naga, batas utara adalah Desa Cigalontang, sebelah timur dibatasi oleh Sungai Ciwulan dan hutan lindung, dan sebelah selatan adalah jalan raya Garut-Tasikmalaya.

\section{Iklim}

Kampung Naga yang terletak di lereng bukit memiliki suhu rata-rata harian $21.5-23^{\circ} \mathrm{C}$ dengan 
kelembaban udara di berkisar 69-97\% (Widianti, 2014). Kelembaban udara yang tinggi terjadi karena faktor sinar matahari. Di dalah perkampungan, rumah yang saling berdekatan ikut menimbulkan kelembaban yang tinggi pada ruang antar bangunan, sehingga aliran udara di ruang antar bangunan dibutuhkan untuk menjaga dan menurunkan kelembaban di dalam kampung. Aliran udara yang diciptakan dari lokasi Kampung Naga di perbukitan, menghasilkan aliran udara timur - barat. Angin lembah berlangsung ketika siang hari, membawa angin dari lembah ke gunung atau dari timur (hunian) ke barat (bukit naga), sedangkan angin gunung terjadi pada malam hari tiupannya berasal dari gunung ke lembah, barat ke timur. Kualitas udara di Kampung Naga sangat baik didukung dengan banyaknya vegetasi di sekitar kampung, serta tidak adanya kendaraan bermotor di dalam kampung.

\section{Topografi}

Desa Neglasari, Kecamatan Salawu, Kabupaten Tasikmalaya berada di ketinggian ratarata 690 mdpl (Kecamatan Salawu dalam Angka, 2018). Kampung Naga, yang terletak di Dusun Naga, Desa Neglasari memiliki ketinggian 600 mdpl - 670 mdpl yang digambarkan dengan garis berwarna hijau, kuning, merah (rendah ke tinggi). Bentuk permukaan tanah di Kampung Naga berupa perbukitan yang cenderung curam di sebelah barat dan makin mendatar di sebelah timur. Daerah yang digunakan sebagai area perkampungan, di sebelah barat Sungai Ciwulan yang melengkung selatan, cenderung landai yaitu di ketinggian $600 \mathrm{mdpl}$, namun sebelah barat elevasi semakin naik menuju ke hutan larangan, pada ketinggian 609 mdpl.

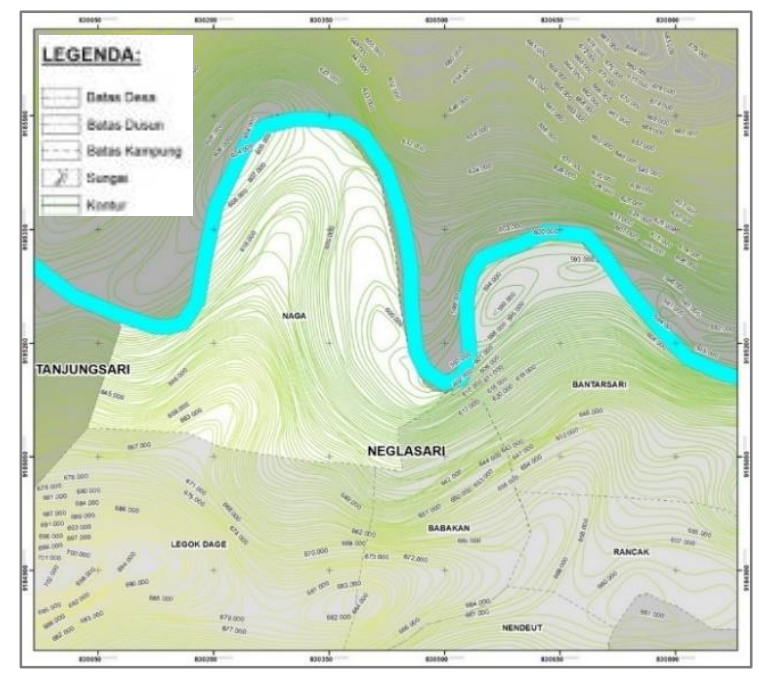

Gambar 2. Peta Topografi

\section{Hidrologi}

Di Kampung Naga air digunakan untuk mandi, mencuci, berwudhu, irigasi sawah, mengairi balong, serta makan dan minum. Badan air yang termasuk ke dalam area kampung Naga adalah Sungai Ciwulan yang berada di sebelah timur kampung, dan balong yang berada di sekitar kampung. Sumber air Kampung Naga berasal dari dua sumber, yaitu dari Sungai Ciwulan dan dari mata air. Sungai Ciwulan berasal dari Gunung Cikuray yang berada di Kabupaten Garut. Sumber air dari Sungai Ciwulan digunakan masyarakat untuk mandi, mencuci, berwudhu, dan untuk mengairi sawah dan balong. Sumber air lainnya adalah dari mata air. Mata air dialirkan menggunakan saluran air buatan yang disebut dengan Saluran Garunggang, dibuat swadaya oleh masyarakat Desa Neglasari untuk mengaliri air bersih ke desanya (Widianti, 2014). Saluran air buatan dari mata air ini berada di sebelah selatan kampung diluar kandang jaga, biasa digunakan oleh masyarakat untuk minum dan memasak karena kondisi airnya yang lebih bersih.

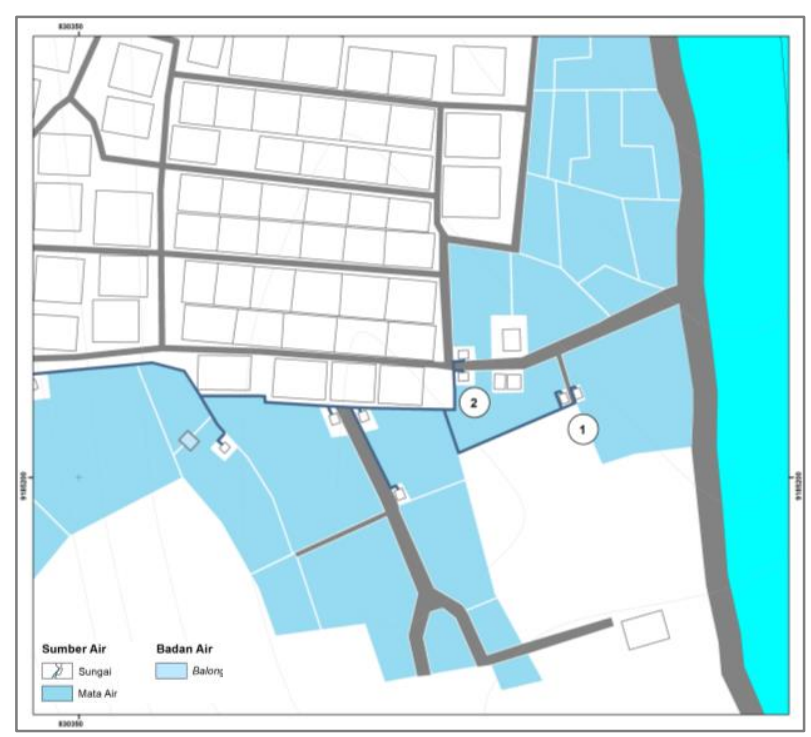

Gambar 3. Peta Hidrologi

\section{Guna Lahan}

Penggunaan lahan di Kampung Naga dibedakan menjadi beberapa macam, yaitu persawahan, hutan, dan hunian. Sawah di Kampung Naga berada di luar kandang jaga, memiliki luas $\pm 3,25$ ha. Kepemilikannya dimiliki secara individual oleh masyarakat Kampung Naga. Irigasi sawah menggunakan air dari Sungai Ciwulan. Sungai Ciwulan berasal dari Gunung Cikuray, Kabupaten Garut. Sungai Ciwulan mengelilingi Kampung Naga di sebelah barat, utara, dan timur. Irigasi sawah berasal dari aliran sungai disebelah barat. Ukuran sawah berbedabeda, dan penempatannya yang berteras-teras 
menyesuaikan dengan kondisi topografi yang berupa perbukitan. Penanaman sawah dilakukan dengan sistem janli atau januari dan juli.

Terdapat dua jenis hutan di Kampung Naga, yaitu hutan produksi dan hutan lindung. Hutan produksi berada di perbukitan sebelah barat dan utara kampung. Hutan ini memiliki luas \pm 4,63 ha dapat dimanfaatkan produk hutannya baik untuk memasak hingga untuk membangun rumah. Hutan lindung adalah hutan dengan minim atau sama sekali tidak ada kegiatan dan produk yang boleh diambil. Di dalam administrasi Kampung Naga hanya terdapat satu hutan lindung, yaitu Leuweung Kramat yang juga merupakan tempat di mana leluhur masyarakan Kampung Naga disemayamkan. Leuweung Kramat memiliki luas 0,1 Ha. Adapula hutan lindung lainnya yang berada di seberang Sungai Ciwulan, yaitu Leuweung Larangan dengan luas 1,32 Ha, walaupun secara administratif berada di luar Kampung Naga, namun hutan ini memiliki makna bagi masyarakat setempat. Leuweung Larangan dianggap masyarakat sebagai penyeimbang agar alam sekitar kampung tetap lestari.

Kawasan hunian merupakan kawasan yang diperuntukkan untuk melakukan kegiatan seharihari bagi masyarakatnya. Hunian berada di dalam area 1,5 hektar yang merupakan tanah adat. Area $1,5 \mathrm{Ha}$ ini merupakan luas yang sudah ditetapkan oleh leluhur sebagai kawasan yang digunakan untuk membangun rumah masyarakat dengan batas hingga mencapa Sungai Ciwulan.

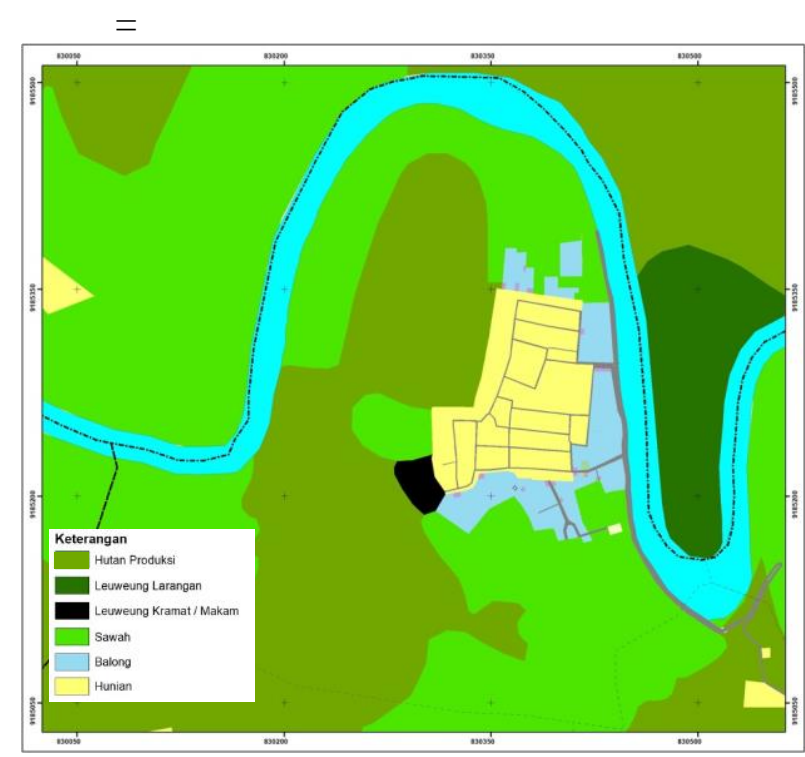

Gambar 4. Peta Guna Lahan

\section{Manusia dan Masyarakat}

Masyarakat Kampung Naga merupakan keturunan asli yang mendiami wilayah tersebut, sedangkan Sanaga adalah seluruh keturunan asli Kampung Naga baik yang tinggal di Kampung
Naga maupun yang tinggal di luar wilayah kampung. Lahan permukiman yang dibatasi hanya 1,5 ha, menjadikan banyak keturunan warga Kampung Naga harus bertempat tinggal di luar Kampung Naga. Dimanapun tempat tinggal warga Sanaga tidak menjadikannya lupa ataupun lepas dari ritual adat yang diadakan di Kampung Naga. Warga Sanaga di luar Kampung Naga masih kerap mengikuti ritual adat, walaupun dalam kesehariannya tidak seperti warga yang tinggal di dalam kampung.

Saat ini, berdasarkan Data Penduduk Kampung Naga (2019), jumlah masyarakat yang tinggal di Kampung Naga adalah 293 jiwa, yang terdiri dari 147 laki-laki dan 146 perempuan yang di dominasi oleh masyarakat berusia 11 hingga 60 tahun. Masyarakat dengan usia angkatan kerja berjumlah 215 jiwa dengan mata pencaharian yang dilakukan beragam, yaitu petani, buruh tani, pns, pedagang, pengrajin, dan lain sebagainya. Masyarakat dengan mata pencaharian petani bekerja di sawah yang dimilikinya disekitar wilayah Kampung Naga dengan waktu panen umumnya pada bulan Januari dan Juli. Pengrajin yang didominasi oleh perempuan membuat beragam kerajinan dari anyaman bambu yang akan dijual di dalam kampung untuk para wisatawan serta di daerah tempat parkir Kampung Naga. Pemandu wisata merupakan mata pencaharian yang para pekerjanya ditunjuk langsung oleh kuncen kampung naga, pemandu wisata mengarahkan dan mengenalkan Kampung Naga kepada para wisatawan yang berkunjung.

\section{Sejarah}

Tidak ada yang mengetahui secara pasti sejak kapan Kampung Naga ada. Seluruh catatan sejarah kampung sudah lenyap terbakar dalam kejadian pembakaran oleh DI/TII tahun 1956. Berdasarkan berbagai sejarah Kampung Naga yang beredar, dapat disimpulkan bahwa Kampung Naga sudah ada semenjak Kerajaan Galunggung berdiri (abad ke-7 hingga abad ke-12), namun tidak diketahui secara pasti kapan tepatnya Kampung Naga didirikan. Kampung Naga ditemukan oleh Eyang Singaparna, selaku orang yang berasal dari Kerajaan Galunggung untuk mencari daerah baru. Ia datang dan membangun rumah pertama di Kampung Naga yang saat ini disebut sebagai Bumi Ageung atau rumah besar atau agung oleh masyarakat Kampung Naga. Masyarakat Kampung Naga hidup dalam damai, namun pada tahun 1956 DI/TII datang dan merusak semuanya, maka dari itu masyarakat parimun obor. 


\section{Kepercayaan}

Seluruh masyarakat Kampung Naga menganut agama Islam, sehingga dari aktivitas dan bagaimana mereka memaknai segala sesuatu berdasarkan pada agama dan syariat Islam. Kampung Naga yang berada di tataran Sunda, masih dipengaruhi adat dan kebudayaan sunda sehingga, aliran kepercayaan Sunda asli masih sedikit mempengaruhi kehidupan masyarakat. Tri Tangtu dina Buana adalah salah satu filosofi sunda yang masih digunakan masyarakat Kampung Naga dalam berkehidupan sehari-hari. Tri Tangtu dina Buana terdiri dari tiga komponen yang saling berhubungan, yaitu Tuhan atau Hiyang/Hyang, alam atau struktur alam semesta, dan manusia.

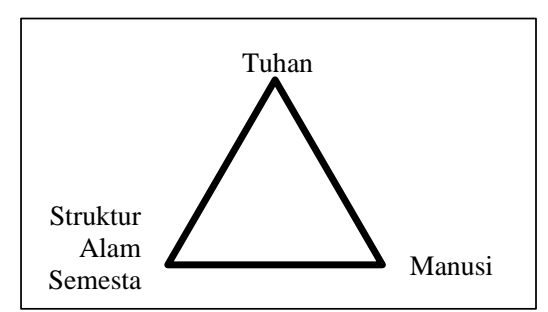

\section{Gambar 5. Struktur Tritangtu Dina Buana}

Di tatar sunda, Agama Islam masuk disaat masyarakat sudah memiliki kepercayaan yang diwariskan dari leluhurnya (Hurgronje, 1931). Kampung Naga memiliki leluhur, Eyang Singaparna, yang dipercaya berasal dari Kerajaan Galunggung yang merupakan kerajaan Islam (DEPDIKBUDRI, 1995). Sehingga tradisi yang Ia bawa ke Kampung Naga juga sudah pencampuran antara Agama Islam, Hindu, Buddha, dan keyakinan tradisional. Dari pencampuran ini, dapat dilihat terapannya di Kampung Naga dalam bentuk pamali, ritual adat, serta bangunan.

1. Pamali merupakan aturan mengenai halhal yang tidak boleh dilakukan, ketika sedang duduk, pamali untuk meluruskan kaki kearah kiblat karena dianggap tidak sopan

2. Pada ritual adat, pencampuran yang jelas terlihat adalah dalam khitanan, walimahan, kematian, dan hajat sasih. Khitanan merupakan sebuah kewajiban bagi laki-laki dalam Islam dan ritual ini juga diterapkan di Kampung Naga dengan tidak meninggalkan keyakinan tradisional di dalamnya dengan menggunakan elemen-elemen ritual. Saat walimahan, yang menjadikannya sah secara Islam adalah dengan adanya mahar, wali nikah, saksi, dan pencatat pernikahan.
Rangkaian lainnya masih mengikuti keyakinan tradisional, seperti nincak endog, dan lainnya. Ritual adat kematian keseluruhannya sudah menerapkan sesuai dengan syariat Islam, mulai dari memandikan jenazah hingga peguburannya. Hajat sasih merupakan ritual adat tersebesar di Kampung Naga yang diadakan enam kali dalam setahun pada hari-hari besar Islam dalam rangka merayakan hari besar Islam tersebut, di dalam rangkaiannya masih terdapat keyakinan tradisional yang dilihat dari penggunaan elemen ritual adatnya.

3. Bangunan Masjid dan Bumi Ageung, selaku rumah leluhur dan tempat menyimpan alat pusaka juga merupakan perwujudan dari pencampuran Islam dan keyakinan tradisional. Di mana masjid sebagai sarana beribadah masyarakat yang menunjukkan Kampung Naga masyarakatnya beragama Islam, dan keberadaan Bumi Ageung yang disakralkan oleh masyarakat karena merupakan milik leluhur.

\section{Ritual adat}

Ritual adat masih dilaksanakan di Kampung Naga sebagai bentuk pewarisan tradisi dan melaksanakan wasiat dan amanat dari nenek moyang. Ritual adat ada yang dilakukan oleh masing-masing individu atau keluarga dan ada yang dilakukan secara bersama-sama oleh seluruh warga Sanaga. Berdasarkan hasil wawancara dengan masyarakat, serta informasi tambahan yang diperoleh dari penelitian terdahulu terkait ritual adat, berikut adalah ritual adat yang dilaksanakan oleh setiap keluarga atau ritual adat domestik mencakup upacara kelahiran, narosan atau pernikahan, kematian, dan bangun rumah. Sedangkan ritual adat komunal, yaitu hajat sasih, agustusan, upacara perayaan panen, dan khitanan massal. Sereh atau lemareun adalah syarat untuk setiap upacara ritual adat. Lemareun berisi sirih, pinang, kapur, dan tembakau. Pelaksanaan dan cara dari tiap ritual berbeda-beda, namun tujuannya sama, yaitu untuk Allah.

\section{Tabel 3. Ritual Adat Kampung Naga}

\begin{tabular}{|c|c|c|c|}
\hline $\begin{array}{l}\text { Ritual } \\
\text { Adat }\end{array}$ & Tujuan & Waktu & Lokasi \\
\hline \multicolumn{4}{|l|}{ Individual } \\
\hline Ngarujak & $\begin{array}{l}\text { Menjaga dan } \\
\text { menghormati hasil } \\
\text { panen padi agar } \\
\text { tetap terjaga }\end{array}$ & $\begin{array}{l}\text { Per } \\
\text { Minggu }\end{array}$ & Goah \\
\hline
\end{tabular}




\begin{tabular}{|c|c|c|c|}
\hline $\begin{array}{l}\text { Ritual } \\
\text { Adat }\end{array}$ & Tujuan & Waktu & Lokasi \\
\hline Lahiran & $\begin{array}{l}\text { Syukuran terhadap } \\
\text { kelahiran seorang } \\
\text { anak }\end{array}$ & \multirow{4}{*}{$\begin{array}{l}\text { Eventua } \\
1\end{array}$} & Rumah \\
\hline $\begin{array}{l}\text { Walimaha } \\
n\end{array}$ & $\begin{array}{l}\text { Menyatukan dua } \\
\text { pasangan secara sah } \\
\text { menurut hukum } \\
\text { negara, adat, dan } \\
\text { agama }\end{array}$ & & $\begin{array}{l}\text { Masjid, } \\
\text { rumah }\end{array}$ \\
\hline Kematian & Mendoakan jasad & & Rumah \\
\hline $\begin{array}{l}\text { Bangun } \\
\text { Rumah }\end{array}$ & $\begin{array}{l}\text { Memohon } \\
\text { kelancaran dari } \\
\text { pembangunan } \\
\text { rumah }\end{array}$ & & Rumah \\
\hline Komunal & & & \\
\hline $\begin{array}{l}\text { Hajat } \\
\text { Sasih/Nu } \\
\text { mpeng }\end{array}$ & $\begin{array}{l}\text { Menghormati } \\
\text { leluhur dan } \\
\text { mensyukuri nikmat } \\
\text { dari Allah SWT } \\
\end{array}$ & \multirow{4}{*}{ Tahunan } & $\begin{array}{l}\text { Masjid, } \\
\text { makam } \\
\text { karuhun }\end{array}$ \\
\hline $\begin{array}{l}\text { Selametan } \\
\text { Padi }\end{array}$ & $\begin{array}{l}\text { Memohon agar padi } \\
\text { tumbuh dengan baik } \\
\text { dan mensyukuri } \\
\text { hasil panen yang } \\
\text { diperoleh }\end{array}$ & & Sawah \\
\hline Agustusan & $\begin{array}{l}\text { Memperingati hari } \\
\text { kemerdekaan } \\
\text { Republik Indonesia }\end{array}$ & & $\begin{array}{l}\text { Bale } \\
\text { Desa }\end{array}$ \\
\hline $\begin{array}{l}\text { Ruwatan } \\
\text { Kampung }\end{array}$ & $\begin{array}{l}\text { Memohon } \\
\text { keselamatan dan } \\
\text { untuk menolak bala }\end{array}$ & & $\begin{array}{l}\text { Kampun } \\
\text { g Naga }\end{array}$ \\
\hline Khitanan & $\begin{array}{l}\text { Menjalani syari'at } \\
\text { Islam, sebagai } \\
\text { bentuk } \\
\text { mengislamkan } \\
\text { seseorang }\end{array}$ & \multirow[t]{2}{*}{$\begin{array}{l}\text { Eventua } \\
1\end{array}$} & $\begin{array}{l}\text { Kampun } \\
\text { g Naga }\end{array}$ \\
\hline Samagaha & $\begin{array}{l}\text { Agar cahaya } \\
\text { matahari kembali } \\
\text { menerangi }\end{array}$ & & $\begin{array}{l}\text { Saung } \\
\text { Lisung }\end{array}$ \\
\hline
\end{tabular}

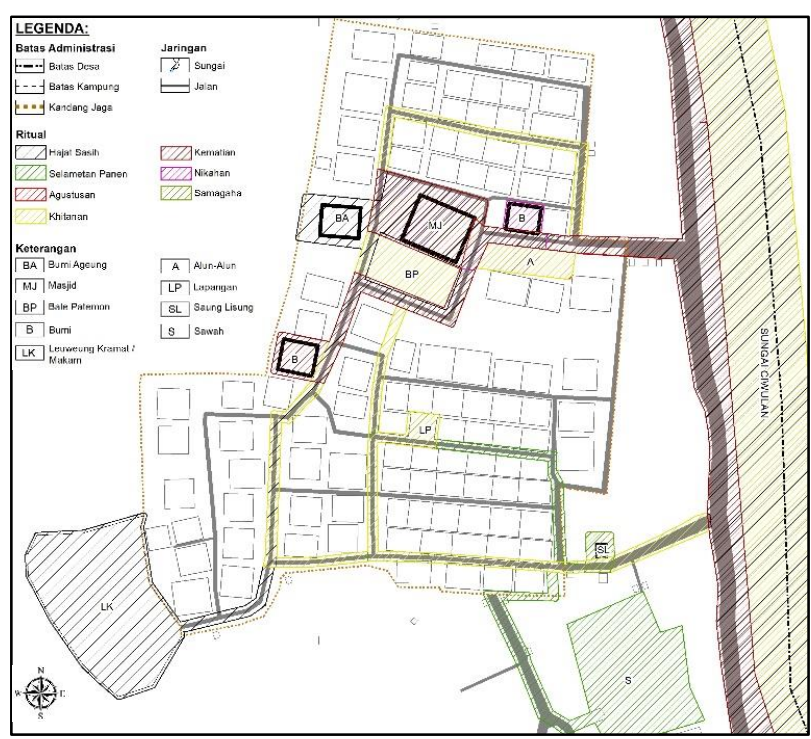

Gambar 6. Peta Ritual Adat Kampung Naga

\section{Bangunan}

Bangunan di Kampung Naga berbentuk rumah panggung yang dianggap cocok untuk daerah tropis. Konstruksi bangunan hanya menggunakan tujuh jenis bahan, yaitu kayu, batu, bambu, tepus, injuk, paku, dan kaca. Atap bangunan terbuat dari tepus dan injuk yang dapat bertahan hingga 35 tahun. Dinding bangunan terbuat dari bambu dan disokong dengan kayu sebagai tiang-tiang penopangnya yang dialasi dengan batu, tidak ada penggunaan tembok atau bata yang disemen sebagai dinding rumah dan bangunan di dalam Kampung Naga. Bangunanbangunan yang terdapat di dalam kandang jaga adalah bumi atau rumah, masjid, bumi ageung, bale patemon, lumbung padi umum. Bangunan yang berada diluar kandang jaga adalah pancuran, saung lisung, dan kandang kambing.

1. Bumi/Rumah

Pembagian ruang dalam rumah terdiri dari 4 bagian, yaitu ruang tamu/tepas, dapur, goah, dan kamar/pangkeng. Namun, ada beberapa rumah yang memiliki luas lebih menambah ruang tengah atau ruang keluarga di dalam rumahnya.

2. Masjid Jami

Masjid, seperti bangunan lainnya di Kampung Naga, berbentuk rumah panggung. Fondasi dan strukturnya sama dengan bangunan rumah. Pintu masuk masjid ada di sebelah utara dan selatan, yang menyambungkannya dengan tempat wudhu. Bangunan masjid merupakan bangunan yang paling besar di Kampung Naga. Masjid berfungsi sebagai tempat ibadah, untuk melaksanakan salat, mengaji, dan juga digunakan sebagai tempat melaksanakan ritual adat. Ritual adat yang dalam prosesinya dilaksanakan di masjid adalah walimahan, salat jenazah, hajat sasih, dan khitanan.

3. Bumi Ageung

Bumi Ageung atau dalam Bahasa Indonesianya berarti rumah besar, merupakan rumah yang pertama kali di bangun di Kampung Naga. Lokasinya berada di sebelah barat masjid. Rumah nenek moyang ini, merupakan salah satu tempat yang dikeramatkan oleh masyarakat. Bumi ageung tidak boleh dimasuki oleh sembarang orang, hanya lembaga adat, seperti kuncen, lebe, dan punduh yang boleh masuk dan hanya pada waktu upacara adat hajat sasih. Rumah ini berisi barang-barang pusaka dan alat-alat yang digunakan saat ritual.

4. Bale Patemon

Bale patemon adalah tempat pertemuan atau ngariungan, serta tempat menyimpan alat kesenian tradisional di Kampung Naga. Apabila ada pengunjung dengan jumlah 
besar yang hadir ke Kampung Naga, maka penerimaan terhadap tamu-tamu tersebut dilakukan di bale patemon. Selain itu, saat upacara khitanan, bale patemon digunakan sebagai tempat tidur bagi peserta khitanan dan kalangkangnya.

5. Lumbung Padi Umum

Waktu panen padi berbeda-beda bagi tiap pemilik sawah. Namun umumnya jatuh pada bulan Agustus dan November. Padi yang sudah dipanen, ada yang digunakan oleh tiap keluarga adapula yang disumbangkan ke kampung. Hasil panen yang disumbangkan ke kampung ini disimpang di lumbung padi atau leuit. Lumbung padi umum merupakan tempat penyimpanan padi yang padinya dapat digunakan untuk makan saat kegiatankegiatan adat dan untuk berjaga-jaga ketika gagal panen dan tidak cukup untuk makan masyarakat.

6. Saung Lisung

Saung lisung berada di luar kandang jaga, dan terletak diatas balong. Saung lisung digunakan sebagai tempat menumbuk padi hasil panen. Alat yang digunakan untuk menumbuk dan memisahkan beras dengan kulitnya adalah lisung dan alu. Ketika menumbuk padi, akan menghasilkan limbah berupa kulit padi atau dedak. Dedak yang dihasilkan dari kegiatan menumbuk, kemudian dijadikan makanan untuk ikanikan yang ada di balong, sehingga tidak ada yang terbuang sia-sia. Selain sebagai penumbuk padi, lesung juga digunakan untuk tetunggulan jika ada upacara adat seperti khitanan dan gerhana matahari.

7. Pancuran

Pancuran atau jamban adalah tempat untuk mandi, cuci, dan kakus. Lokasinya berada di luar kandang jaga karena dianggap kotor dan polutif. Hal ini dikarenakan kegiatan yang dilakukan di dalam pancuran menghasilkan limbah. Limbah yang dihasilkan ini langsung jatuh ke balong dan menjadi makanan ikan. Air yang digunakan dalam pancuran berasal dari Sungai Ciwulan dari sebelah barat bukit dengan menggunakan pipa.

8. Kandang Hewan

Tempat menyimpan hewan kambing.

Kandang diletakkan diluar karena bersifat polutif, dan menghasilkan limbah.

\section{Jalur Sirkulasi}

Pencapaian menuju Kampung Naga cukup mudah, karena lokasinya yang berada dekat dengan jalan raya Garut-Tasikmalaya. Perjalanan masuk menuju kampung adat hanya memiliki satu jalur, yaitu dengan menuruni 439 anak tangga yang terbuat dari batu. Ketika memasuki tanah adat Kampung Naga, dapat terlihat jelas batas antara kampung dengan daerah luarnya, yaitu dengan keberadaan kandang jaga. Gerbang utama untuk memasuki Kampung Naga berada segaris lurus dengan masjid, namun ada beberapa jalan masuk lainnya yang lebih kecil, namun masih bisa dilalui. Di dalam areal perkampungan, semua ruas bisa dijadikan jalan, baik antar rumah dan sekatsekat lainnya.

Ruas jalan dalam kampung juga dijadikan sebagai ruang untuk ritual masyarakat. Ritual yang menggunakan ruas jalan dalam pelaksanaannya adalah ritual hajat sasih, khitanan, dan walimahan. Ketika pelaksanaan ritual hajat sasih, jalan yang digunakan adalah jalan dari Sungai Ciwulan ke Masjid dan Bumi Ageung, dan jalan dari Masjid ke leuweung kramat. Ritual khitanan hampir menggunakan seluruh jalan di kampung dalam posesi arakarakannya. Jalan yang digunakkan untuk walimahan adalah jalan depan rumah pengantin perempuan atau halaman depan rumahnya.

Jaringan sumber air di Kampung Naga dialirkan menggunakan pipa-pipa. Sumber air, seperti yang sudah dibahas sebelumnya, terdiri dari dua, yaitu Sungai Ciwulan dan sumber mata air. Sumber air dari Sungai Ciwulan yang berada di barat kampung yang berasal dari hulu Gunung Cikuray, digunakan untuk mencuci, berwudhu, mandi, irigasi sawah dan balong. Air Sungai Ciwulan yang berada di barat kampung ini dialirkan menggunakan Saluran Garunggung. Air yang berasal dari Saluran Garunggung dialirkan ke bak penyeringan untuk disaring secara senderhana, baru dialirkan dengan pipa untuk kegunaan masyarakat sehari-hari. Di timur kampung ada Sungai Ciwulan yang menjadi buangan terakhir setelah digunakan oleh masyarakat.

Di dalam perkampungan Kampung Naga dan di batas-batasnya, terdapat parit-parit kecil yang digunakan sebagai jalan air yanag mengalir dari dataran yang lebih tinggi di sebelah barat, ke dataran yang lebih rendah di sebelah timur. Parit ini mengalir air yang bersumber dari air hujan yang tidak terserap dalam area hunian masyarakat. Parit dibangun agar wilayah perkampungan tidak mudah tergenang air apabila musim penghujan datang. Air akan dengan mudah mengalir turun 
balong hingga berkahir ke Sungai Ciwulan tanpa membanjiri Kampung Naga.

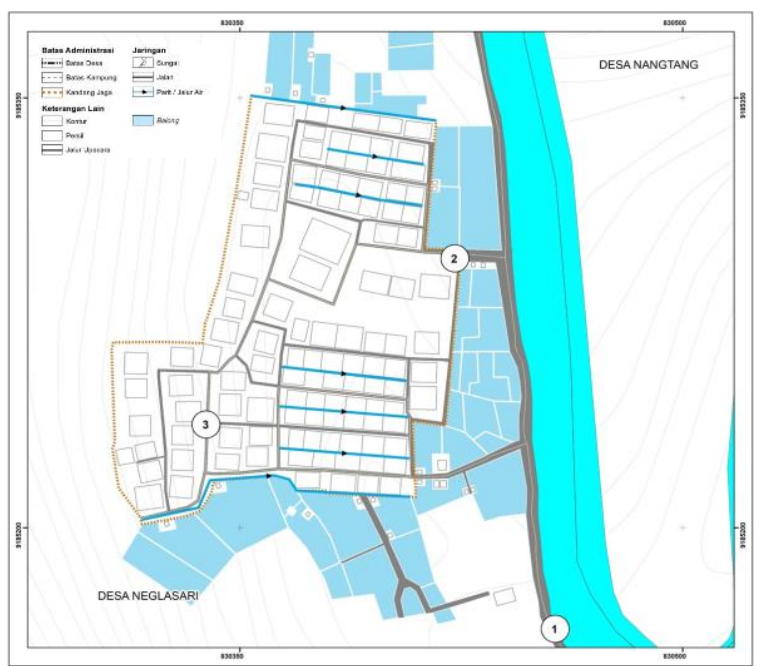

Gambar 7. Jalur Sirkulasi Air

\section{KESIMPULAN}

Berdasarkan hasil penelitian, dapat diketahui kesimpulan sebagai berikut:

1. Elemen pembentuk permukiman fisik terdiri dari iklim, topografi, hidrologi, dan guna lahan. Kampung Naga memiliki suhu rata-rata $21.5^{\circ} \mathrm{C}$, dengan aliran udara yang diciptakan adalah timur-barat. Berada di ketinggian ratarata $600 \mathrm{mdpl}$. Sumber air berasal dari mata air dan Sungai Ciwulan yang dialirkan menggunakan Saluran Garunggung. Penggunaan lahannya terbagi menjadi hutan lindung, hutan produksi, sawah, dan hunian.

2. Masyarakat keturunan Kampung Naga disebut dengan Sanaga, dengan nenek moyangnya adalah Eyang Singaparna. Seluruh masyarakatnya beragama Islam dengan percampuran dengan keyakinan tradisional dan agama sebelumnya. Percampuran ini dirasakan ketika pelaksanaan ritualnya. Terdapat dua jenis ritual, yaitu ritual individu dan ritual komunal.

3. Area Kampung Naga dipisahkan dengan kandang jaga yang membagi daerahnya jadi bagian dalam dan luar. Bangunan di Kampung Naga yang berada di dalam kandang jaga adalah rumah, masjid, bumi ageung, bale patemon, lumbung padi umum, sedangkan yang berada diluar kandang jaga adalah pancuran, saung lisung, dan kandang kambing.

4. Sirkulasi dalam kampung menggunakan ruasruas antar bangunan sebagai jalan, serta terdapat parit-parit kecil untuk mengalirkan air agar tidak membanjiri kampung.

5. Content dan container dalam kampung saling timbal balik dalam membentuk kampung, dengan elemen manusia dan masyarakat yang paling berkontribusi dalam membentuk permukiman tradisional.

\section{DAFTAR PUSTAKA}

Ayunurafidha, Arnes. 2015. "Pola Permukiman Tradisional Dusun Krajan Kecamatan Senduro Kabupaten Lumajang." Universitas Brawijaya.

Dariwu, C. T., J. O. Waani, \& F. Warouw. 2016. "Ekistics Dalam Permukiman Nelayan Pesisir Pantai Sindulang Satu." Media Matrasain 13(2):1-14.

Doxiadis, Constantinos Apostolou. 1968. Ekistics: An Introduction to the Science of Human Settlements. UK: Hutchinson \& Co.

Haryadi, \& B. Setiawan. 1995. Arsitektur Lingkungan Dan Perilaku. Jakarta: P3SL Dirjen Dikti Dep-dikbud.

Jencks, Charles, \& Karl Kropf. 1981. Theoris and Manifastoes of Contemporary Architecture. London.

Nawawi, H. Hadari, \& H. Mimi Martini. 1996. Penelitian Terapan. Yogyakarta: Gadjah Mada University Press.

Niracanti, Galuh Aji. 2001. "Studi Perubahan Penggunaan Ruang Permukiman Kampung Kauman Semarang." Universitas Diponegoro.

Payong, Yohannes Kapistranus Sasong. 2016. "POLA PERMUKIMAN KAMPUNG ADAT LEWOHALA DI KABUPATEN LEMBATA-FLORES PROVINSI NUSA TENGGARA TIMUR.” Jurnal Ruang Space 3(2):215-32.

Rakhmawati, Ekahayu, Antariksa, \& Fadly Usman. 2009. "Pola Permukiman Kampung Kauman Kota Malang." Arsitektur EJournal 2(3):160-78.

Sasongko, Ibnu. 2005. "Pembentukan Struktur Ruang Permukiman Berbasis Budaya." DIMENSI (Journal of Architecture and Built Environment) 33(1):1-8.

Widianti, Novita Tresna. 2014. "Studi Potensi Kampung Naga Sebagai Sebuah Ecovillage." Institut Pertanian Bogor. 
ELEMEN PEMBENTUK PERMUKIMAN TRADISIONAL KAMPUNG NAGA 